are unstable after manipulative reduction, yet operative methods, particularly for the radial dislocation, increase the risk of complication's. Most surgeons advise operative reduction of the fracture of the ulna, with internal fixation by means of a plate, a bone graft, or an intramedullary nail. At the same time the head of the radius is replaced by manipulation. A full-length arm plaster is applied with the elbow flexed to the right-angle, and immobilization is continued until union of the fracture is present. The success of this line of treatment may be impaired by the occurrence of certain wellrecognized complications. First, attempts to replace the head of the radius by manipulation may fail, or redisplacement may occur after initial reduction. Although this difficulty can be overcome by operative reduction with suture of the orbicular ligament or by excision of the head of the radius, these procedures considerably increase the risk of ossification of the surrounding haematoma and are reluctantly undertaken only in cases in which the injury is recent. Secondly, there may be delayed union or non-union of the ulnar fracture, demanding further operative treatment and further prolonged immobilization. Thirdly, in spite of the most careful treatment, ossification of the haematoma around the elbow-joint is a not infrequent occurrence and leads to serious limitations of elbow movements.

\section{Hormone Treatment of Mastitis}

Q.-What are the relative merits of oestrogens, progesterone, and testosterone in the treatment of chronic mastitis? What is the recommended dosage of each?

A.- The optimum and, in fact, the only logical treatment of chronic mastitis is testosterone if we subscribe to the generally accepted view that this condition is due to excessive stimulation of the breast tissue by an abnormally high level of oestrogens. If the dose of testosterone is large-e.g., $600 \mathrm{mg}$. by implantation or $25 \mathrm{mg}$. daily by injection-the function of the ovary is completely suppressed and the breasts tend to atrophy. Smaller doses, varying with individual cases, will produce a modifying but less absolute effect and without the disadvantage of producing hirsutism and virilism. These changes are produced by inhibition of the secretion of the pituitary gonadotrophic hormones. A more direct local action, antagonistic to oestrogens, appears to be produced by local inunction of testosterone in the form of an ointment, some $50 \mathrm{mg}$. a week or less being adequate. Oestrogens and progesterone are sometimes prescribed on the theory that before menstruation tension is felt in the breast region when the breast structure, ducts and acini respectively, are not completely developed. This may be the case in a small proportion of patients.

\section{Incision of the Hymen}

Q.-What is the most suitable local analgesic for division of a tough hymen? How much should be used and at what point should it be injected? What is the best technique immediately and post-operatively?

A.-A $1 \%$ solution of procaine could be used to infiltrate the posterior and lateral tissues of the introitus and lower vagina at the level of the attachment of the hymen, and incisions could then be made postero-laterally. If the indication is dyspareunia or apareunia, however, this operation is not recommended. Incision of the hymen alone gives unsatisfactory results, because in many cases the whole introitus rather than the hymen appears resistant and nearly always there is an important element of vaginismus, at any rate by the time the patient seeks advice. Moreover, the woman who suffers long-standing apareunia is usually so nervous and apprehensive that it is unwise to attempt any procedure under local analgesia.

Apareunia in recently married women without gross vaginismus is mainly due to ignorance; a little instruction and perhaps the daily use of graduated vaginal dilators by the patient herself for a few weeks is all that is required. When, however, the difficulty is long standing and vaginismus is present it is usually necessary to carry out a digital dilatation of the introitus and vagina (this involves stretching or tearing the hymen) under general anaesthesia. After this the patient is instructed in the use of vaginal dilators daily for three weeks. The object of these is not to dilate the vagina further but to allow the patient to convince herself that any previous obstruc- tion to coitus has been removed and to restore her confidence. The tendency to muscle spasm persists for a time, but this can be overcome by leaving a large-size dilator in the vagina for 10 to 15 minutes. Relaxation of the pelvic floor muscles is also favoured by telling the woman to concentrate on forcibly abducting the thighs when she is lying in the dorsal position with the knees flexed.

\section{Erythema Nodosum and Ringworm Infections}

Q.-Is erythema nodosum a recognized accompaniment of animal ringworm infections? A young farm labourer had animal ringworm, affecting principally the forehead, and painful shins. The lesions on his shins were undoubtedly those of erythema nodosum.

A.- Erythema nodosum is one of the recognized patterns of allergic reaction to ringworm infections-an "ide" reaction, more common with the animal large-spore ringworms than with other types of infection.

\section{Snoring}

Q.-A man aged 30 who is about to get married snores loudly. He sleeps with his mouth shut, he has no obvious clinical obstruction in the upper respiratory tract, and he seems healthy. Is there a remedy?

A.- Snoring is in most cases due to the tongue falling back during sleep. In the absence of nasal obstruction or disease the usual cause is sleeping on the back. An o.d and simple means of avoiding this is to strap a small hard object on the middle of the back, so that the sleeper turns for comfort on to his side. The causes and treatment of snoring were discussed by the Section of Laryngology of the Royal Society of Medicine last year, and a report of this discussion appeared in the Journal $(1947,2,835)$.

\section{NOTES AND COMMENTS}

Embalming.-Dr. P. W. HAMPToN (Onchan, Isle of Man) writes: Your correspondent (July 31, p. 279) who wishes for a simple method of embalming might be interested in the way in which it is done in the transpacific emigrant trade. It is part of the contract that the body of a Chinese passenger dying en voyage shall be returned to the Celestial Empire for burial. A layer of ashes from the stokehole is spread at the bottom of the coffin and chloride of lime (chlorinated lime) is liberally sprinkled over this. The body is then laid on top and formalin ( $40 \%$ formaldehyde solution) is injected at various points: neck, right and left sides of chest, abdomen at three or four places, and both thighs. Formalin is then poured into the open mouth and sprinkled all over the body; then chloride of lime again, and finally the coffin is filled with ashes. A four-ounce syringe is used with a wide-bore needle, and a quart jugful of formalin is sufficient. Of course this method is impracticable if the relatives wish to view the body at the end of the voyage. I have embalmed seven Chinese on a voyage from British Columbia to Hong Kong and can vouch for the soundness of this method.

\section{Corrections}

Dr. St. G. B. D. Gray (London, E.17) writes: May I correct a numerical error in my letter on children's medicines (Supplement, Aug. 21, p. 91) ? "Suspension sulphathiazolis" contains 2 grammes (= 4 tablets) per ounce (not 4 grammes as I stated).

In the article entitled "Modern Therapy of Benign Tertian Malaria " by Dr. J. F. Monk in the Journal of June 26 there is a misprint at the foot of p. 1224. The dose of quinine in the quininepamaquin regime should be $10 \mathrm{gr}$., not $10 \mathrm{~g}$. All communications with regard to editorial business should be addressed to THE
EDITOR, BRITISH MEDICAL JouRnAL, B.M.A. HoUSE, TAVISTOCK SQUARE, EDITOR, BRITISH MEDICAL JOURNAL, B.M.A. HOUSE, TAVISTOCK SQUARE,
LONDON, W.C.1. TELEPHONE: EUSTON 2111. TELEGRAMS: Aitiology, LONDON, W.C.1. TELEPHONE: EUSTON 2111. TELEGRAMS: Aitiology, Westcent, London. ORIGINAL ARTICLES AND LETTERS forwarded for publicarion are understood to

unless the contrary be stated.
Authors desiring REPRINTS should communicate with the Publishing Manager, B.M. H. House. Tavistock Square, W.C.1, on receipt of proofs. Authors B.M.A. House, Tavistock Square, W.C.1, on receipt of proofs. Authors
overseas should indicate on MSS, if reprints are required, as proofs are not overseas should

DVERTISEMENTS should be addressed to the Advertisement Manager B.M.A. House, Tavistock Square, London, W.C.1 (hours 9 a.m. to 5 p.m.) TELEPHONE : EUSTON 211. TELEGRAMS: Britmedads, Westcent London. MEMBERS SUBSCRIPTIONS should be sent to the SECRETARY of the London.

B.M.A. SCotrish OFFICE: 7, Drumsheugh Gardens, Edinburgh. 